\title{
A new way of setting rFSH deposit: a case of severe injection error in IVF/ICSI cycle ending with live birth
}

\section{Depo rFSH yerlesstirmenin yeni bir yolu: canlı doğumla sonuçlanan IVF/ICSI döngüsünde bir ciddi enjeksiyon hatası olgusu}

\author{
Richard Bernhard Mayer, Thomas Ebner, Omar Shebl, Gernot Tews \\ Landes-Frauen-und Kinderklinik, Kinderwunsch Zentrum, Linz, Austria
}

\begin{abstract}
We present a case with a severe injection error: a 25- year old woman with secondary infertility caused by a male factor was enrolled in our IVF/ICSI-ET program. Stimulation was performed in a long- protocol and ovarian stimulation, using $\mathrm{rFSH}$ follitropin beta, starting on the third day of the menstrual cycle. The rFSH dose per day was 900 IU-0 IU-0 IU-0 IU. Due to normal ovarian response and follicle growth, stimulation was continued and there was no detriment in oocyte quality and no symptoms of OHSS. Following blastocyte transfer cesarean section was unpreventable at $37+5$ weeks of gestation due to an impacted transverse lie. Different stimulation protocols are needed for appropriate treatment of various patients provided that the administration of treatment was done correctly. In the case of injection errors, continuing stimulation protocol seems to be achievable in certain cases considering hormone levels and the process of follicle growth. (J Turkish-German Gynecol Assoc 2012; 13: 215-7)
\end{abstract}

Key words: Assisted reproductive technique, severe injection error, long protocol, $\mathrm{rFSH}$, live birth

Received: 18 November, 2011

Accepted: 03 January, 2012
Özet

Ciddi enjeksiyon hatası olan bir olgu sunuyoruz: Erkek faktörünün yol açtığı ikincil infertilitesi olan 25 yaşındaki bir kadın IVF/ICSI-ET programımıza alındı. Stimulasyon uzun protokol ile gerçekleştirildi ve over stimulasyonu, $\mathrm{rFSH}$ follitropin beta kullanılarak, menstrüel döngünün üçüncü günü başlatıldı. Günlük rFSH dozu şöyleydi: 900 IU-0 IU-0 IU-0 IU. Normal over yanıtı ve folikül büyümesi nedeniyle stimulasyona devam edildi, oosit kalitesinde bozulma ve OHSS semptomlan yoktu. Blastokist transferini takiben sezaryenle doğum, kalıcı transvers duruş nedeniyle 37+5'inci gebelik haftasında önlenemez durumdaydı. Çeşitli hastaların uygun tedavisi için, tedavi uygulamasının doğru bir şekilde yapılmasını sağlayan, farklı stimulasyon protokollerine gerek duyulmaktadır. Enjeksiyon hataları durumunda, hormon düzeyleri ve folikül büyümesi süreci göz önüne alınarak, stimulasyon protokolünün sürdürülmesi bazı olgularda başarılabilir görünmektedir.

(J Turkish-German Gynecol Assoc 2012; 13: 215-7)

Anahtar kelimeler: Yardımlı üreme tekniği, ciddi enjeksiyon hatası, uzun protokol, $\mathrm{rFSH}$, canlı doğum

Geliş Tarihi: 18 Kasım 2011

Kabul Tarihi: 03 Ocak 2012

\section{Introduction}

Woman suffering fertility problems and their partners are confronted with significant psychosocial consequences. The prevalence of negative emotions, psychological distress and changes in inter-partner relationships have been reported (1). These emotional feelings may worsen during ovarian stimulation for different reasons. One reason seems to be the need of self-injections, the impact on everyday life by the injection regimen and, especially, concerns relating to the correct practical application of gonadotrophins. It seems important to recognise that only $29 \%$ of patients actually report an injection error to their physician or nurse (2).

These injection errors need to be analysed individually and can hardly be categorised. However, the outcome of infertility treatment depends on the correct application of gonadotrophin products, which in turn could gain an influence on oocyte quality.

Indeed, this hypothesis is supported by the literature. In detail, influence on the zona score of mature gametes was affected by stimulation details (3). Furthermore, ovarian hyperstimula- tion syndrome may be determined and high estradiol levels could be one of the causes of smooth endoplasmatic reticulum clusters in MII human oocytes, which are associated with lower chances of successful pregnancy (4).

The study was approved by our institutional review board and informed consent of the patient had been obtained.

\section{Case Report}

In 2010, a 25- year old woman with secondary infertility caused by a male factor-OAT was enrolled in our IVF/ICSI-ET program. Sperm analyses in detail were: concentration 2.5 millions/mL, progressive motility $12 \%$ ( $0 \%$ fast progressive) normal morphology $1 \%$. She had a history of spontaneous pregnancy and delivery in 2005 with the same male partner. The patient presented with a normal AMH level of $1.67 \mathrm{ng} / \mathrm{mL}$, $75 \mathrm{~kg}$ body weight and a BMI of 27 . Serum FSH concentration was $5.8 \mathrm{mU} / \mathrm{mL}$ measured in precycle.

Stimulation was performed in a long- protocol, undergoing down-regulation with the GnRH-analague buserelin acetate (Metrelef®, Ferring, Germany, $0.15 \mathrm{mg}, 3 \times 2$ puffs/day) started 
on the $21^{\text {st }}$ day of precycle and ovarian stimulation using $\mathrm{rFSH}$ follitropin beta (Puregon ${ }^{\circledR}$, Organon, Netherlands) started on the third day of the menstrual cycle. Hormone levels measured on the second day of the menstrual cycle: estradiol $20.7 \mathrm{pg} /$ $\mathrm{mL}$, progesterone $0.4 \mathrm{ng} / \mathrm{mL}$, LH $2.2 \mathrm{mU} / \mathrm{mL}$. Luteal phase support was via progesterone $400 \mathrm{mg}$ vaginal suppositories. The recommended daily dose of $\mathrm{rFSH}$, started on the third day of menstrual cycle, was 200 IU-200 IU-150 IU-150 IU. Follow-up was planned on the $5^{\text {th }}$ day of stimulation measuring the ovarian follicles and estradiol, progesterone and LH hormone levels. The actual rFSH dose per day, injected by the male partner, was 900 IU-0 IU-0 IU-0 IU. On the fifth day of stimulation the five leading follicles reached $12 \mathrm{~mm}$ in $2 \mathrm{D}$ plane, hormone- levels: estradiol $405.0 \mathrm{pg} / \mathrm{mL}$, progesterone $0.6 \mathrm{ng} / \mathrm{mL}$, LH $1.8 \mathrm{mU} / \mathrm{mL}$. rFSH stimulation was continued using 200 IU-150 IU-150 IU. After these three days of stimulation the leading follicle reached $16.5 \mathrm{~mm}$; hormone levels: estradiol $1994.0 \mathrm{pg} / \mathrm{mL}$, progesterone $0.6 \mathrm{ng} / \mathrm{mL}$, LH $3.9 \mathrm{mU} / \mathrm{mL}$. Stimulation was continued for another two days using 150 IU-150 IU of rFSH. Estradiol level reached on the day of $\beta$-hCG application-chorionic gonadotrophin alpha (Ovitrelle ${ }^{\circledR} 250 \mu \mathrm{g}$, Merck Serono)-was $3608 \mathrm{pg} / \mathrm{mL}$, progesterone level was $1.1 \mathrm{ng} / \mathrm{mL}$, LH level was $2.1 \mathrm{mU} / \mathrm{mL}$ and the two leading follicles reached $20 \mathrm{~mm}$, measured in 2 -D plane. Finally, 13 oocytes were retrieved and a single blastocyst- transfer using a blastocyst of optimal quality of inner cell mass and good quality of trophectoderm (Vab) was performed; all the rest stopped development. 10 days after embryo transfer, $\beta$-hCG reached $248 \mathrm{mU} / \mathrm{mL}$, progesterone was $11 \mathrm{ng} / \mathrm{mL}$ and at $6+6$ weeks of gestation an intact pregnancy with CRL $6 \mathrm{~mm}$ was diagnosed.

As a result of major relationship problems an appointment for medically induced abortion was made, although psychological support is offered routinely to all patients undergoing an IVF/ ICSI- cycle at our clinic. Although the consent form was already signed, the patient ultimately decided not to perform the abortion. At eleven weeks of gestation the patient suffered a psychological breakdown with suicidal thoughts and was transferred to the General Psychological Hospital in Linz, Upper Austria. After five days of inpatient treatment an adjustment disorder with depressive reaction was diagnosed and the patient could be discharged without medical treatment.

At $37+5$ weeks of gestation the patient presented with an impacted transverse lie and a cesarean section was performed. The birth weight of the neonate was $3600 \mathrm{~g}$, Apgar score was $8 / 9 / 10$ and $\mathrm{pH}$ was 7.29 and 7.32 , respectively.

\section{Discussion}

The application of $900 \mathrm{IU}$ rFSH represents a severe injection error which could only be done by using the injection pen twice and the pen even needs to be reloaded. The application was performed by the male partner of our patient. Both, patient and male partner, had not recognised that the injection pen was blank after the first day of stimulation although they had received an appropriate course of instruction for self-injection. As a consequence, a three-day period without gonadotrophin stimulation ensued. In addition to regular follicle recruitment and usual serum hormone levels, the stimulation protocol was continued.

The injection error presented involves two separate problems, namely OHSS and follicle growth arrest. Because of the relatively short elimination (terminal) half-life $(\mathrm{t} 1 / 2)$ of rFSH of about 30-40h, daily injections are needed to keep the serum concentration above the threshold required for follicular recruitment and ongoing maturation. Peak serum FSH levels are reached 10-12 $\mathrm{h}$ after application and then decline until the next injection; thus, usually 3- 5 days of treatment are needed to reach $\mathrm{FSH}$ steady-state levels during ovarian stimulation $(5,6)$. Following these pharmacokinetics, FSH serum concentration seemed above the threshold in this case, because of the high peak serum level after application of $900 \mathrm{IU}$, even considering the short elimination half-life. As a consequence, there was no follicle growth arrest and continuing the stimulation protocol showed a normal follicle growth. Thus, there was no detriment to oocyte quality.

The response to gonadotrophins is highly variable, and a certain proportion of women exhibit an unexpectedly poor response to stimulation. Ovarian response shows a strong correlation with serum anti-Müllerian hormone (AMH) levels (7). Regardless of the antral follicle count, anti-Müllerian hormone seems to be the most significant predictor of poor response in controlled ovarian stimulation (8), which was within normal, age-related range for our patient (9).

Other patients demonstrate an exaggerated response and are at risk of developing an OHSS. Risk factors for the development of OHSS include young age, low body mass index, previous OHSS, high antral follicle count, polycystic ovaries and elevated peak serum estradiol $(10,11)$. The pathophysiology of OHSS is controversial, but circulating estradiol levels have been suggested to be of predictive value for OHSS, regardless of the actual role

Table 1. Stimulation protocol including hormone levels, follicle size in 2-D plane and rFSH IU used (follitropin beta, Puregon ${ }^{\circledR}$, Organon, Netherlands)

\begin{tabular}{|c|c|c|c|c|c|c|c|c|c|c|c|}
\hline Day of menstrual cycle & 2. & 3. & 4. & 5. & 6. & 7. & 8. & 9. & 10. & 11. & 12. \\
\hline rFSH (IU) & & 900 & - & - & - & 200 & 150 & 150 & 150 & 150 & $>$ \\
\hline Estradiol (pg/mL) & 20.7 & & & & & 405 & & & 1994 & & 3608 \\
\hline $\mathrm{LH}(\mathrm{mU} / \mathrm{mL})$ & 2.2 & & & & & 1.8 & & & 3.9 & & 2.1 \\
\hline Follicle (mm) & & & & & & $\begin{array}{l}12 \\
11\end{array}$ & & & $\begin{array}{c}16.5 \\
16 \\
16\end{array}$ & & $\begin{array}{c}20.5 \\
20 \\
19\end{array}$ \\
\hline
\end{tabular}


of estradiol in the pathogenesis (12). In our case, the estradiol level reached $3608 \mathrm{pg} / \mathrm{mL}$ and no OHSS could be recognised. Specific subgroups of women may even benefit from LH activity supplementation during ovarian stimulation, such as patients older than 35 years and patients with suboptimal IVF outcome and normogonadotrophic patients with `steady response` (13). As a consequence, different stimulation protocols are needed for appropriate treatment of different patients, provided that administration of treatment was performed correctly. Injection errors seem to occur in about $2.3 \%$ of IVF/ICSI cycles. Even if the pregnancy rate following an injection error is only $7 \%$ in our own unpublished data, continuing the stimulation protocol seems to be achievable in certain cases.

\section{Conflict of interest}

No conflict of interest was declared by the authors.

\section{References}

1. Oddens BJ, Tonkelaar I, Nieuwenhuyse H. Psychosocial experiences in woman facing fertility problems - a comparative survey. Hum Reprod 1999; 14: 255-61. [CrossRef]

2. Huisman D, Raymakers X, Hoomans EHM. Understanding the burden of ovarian stimulation: fertility expert and patient perceptions. RBM Online 2009; 19: 5-10.

3. Ebner T, Balaban B, Moser M, Shebl O, Urman B, Ata B, et al. Automatic user-independent zona pellucida imaging at the oocyte stage allows for the prediction of preimplantation development. Fertil Steril 2010; 94: 913-20. [CrossRef]

4. Otsuki J, Okada A, Morimoto K, Nagai Y, Kubo H. The relationship between pregnancy outcome and smooth endoplasmic reticulum clusters in MII human oocytes. Hum Reprod 2004; 19: 1591-7.
[CrossRef]

5. Mannaerts BMJL, Rombout F, Out HJ, Coelingh Bennink H. Clinical profiling of recombinant follicle stimulating hormone $(\mathrm{rFSH}$; Puregon): relationship between serum FSH and efficacy. Hum Reprod 1996; 2: 153-61. [CrossRef]

6. Mannaerts BMJL, Shoham Z, Schoot D, Bouchard P, Harlin J, Fauser BCJM, et al. Single- dose pharmacokinetics and pharmacodynamics of recombinant human follicle-stimulating hormone (Org 32489) in gonadotropin-deficient volunteers. Fertil Steril 1998; 69: 15-20. [CrossRef]

7. La Marca A, Giulini S, Tirelli A, Berucci E, Marsella T, Xella S, Volpe A. Anti-Müllarian hormone measurement on any day of the menstrual cycle strongly predicts ovarian response in assisted reproductive technology. Hum Reprod 2007; 22: 766-71. [CrossRef]

8. Jayaprakasan K, Campbell B, Hopkisson J, Johnson I, Rain-Fenning N. A prospective, comparative analyses of anti-Müllarian hormone, inhibin-B, and three-dimensional ultrasound determinants of ovarian reserve in the prediction of poor response to controlled ovarian stimulation. Fertil Steril 2010; 93: 855-64. [CrossRef]

9. Shebl O, Ebner T, Sir A, Scheier-Lechner E, Mayer RB, Tews G, et al. Age- related distribution of basal serum AMH level in woman of reproductive age and a presumable healthy cohort. Fert Stert 2011; 95: 832-4. [CrossRef]

10. Navot D, Bergh PA, Laufer N. Ovarian hyperstimulation syndrome in novel reproductive technologies: prevention and treatment. Fertil Steril 1992; 58: 249-61.

11. Delvigne A, Demoulin A, Smitz J, Donnez J, Koninckx P, Dohnt M, et al. The ovarian hyperstimulation syndrome in in-vitro fertilization: a Belgian multicentric study. I. Clinical and biological features. Hum Reprod 1993; 8: 1353-60.

12. Aboulghar M. Prediction of ovarian hyperstimulation syndrome (OHSS). Estradiol level has an important role in the prediction of OHSS. Hum Reprod 2003; 18: 1140-1. [CrossRef]

13. Alviggi C, larizia R, Mollo A, Ranieri A, De Placido G. Who needs LH in ovarian stimulation? RBM Online 2006; 12: 599-607.

\section{ERRATUM}

Author names of the article titled "Iliofemoral-popliteal deep vein thrombosis at 35" week of pregnancy: treated with cesarean section and vena cava blockage plus thrombectomy-Gebeliğin 35. haftasında iliofemoralpopliteal derin ven trombozu olan sezaryen seksiyo, vena kava blokaji ve trombektomi ile tedavi edilen olgu sunumu" which was published in the Journal of the Turkish-German Gynecological Association's $13^{\text {th }}$ Volume, $2^{\text {nd }}$ issue, on pages 139-141 from the year 2012 were published incorrect due to a technical error and the correct versions are as stated below. We hereby correct this error and apologize from our readers.

K. Mehmet Burgazlı1 ${ }^{1}$, Metin M. Altay², Hakan Akdere ${ }^{3}$, Mehmet Bilgin ${ }^{4}$, Ethem Kavukcu $^{5}$, Horst Kill ${ }^{6}$, Werner Päfgen ${ }^{6}$, A. Kubilay Ertan ${ }^{2}$

'Department of Internal Medicine, Cardiology, Angiology, University Clinic of Giessen, Giessen, Germany ${ }^{2}$ Department of Gynecology and Obstetrics, Hospital of Leverkusen, Leverkusen, Germany ${ }^{3}$ Department of Urology, Medical Center Wuppertal, Wuppertal, Germany ${ }^{4}$ Department of Radiology, Faculty of Medicine, Bezmialem Vakıf University, İstanbul, Turkey ${ }^{5}$ Department of Internal Medicine, Medical Center Wuppertal, Wuppertal, Germany

${ }^{6}$ Department of Vascular Surgery, Hospital of Leverkusen, Leverkusen, Germany 